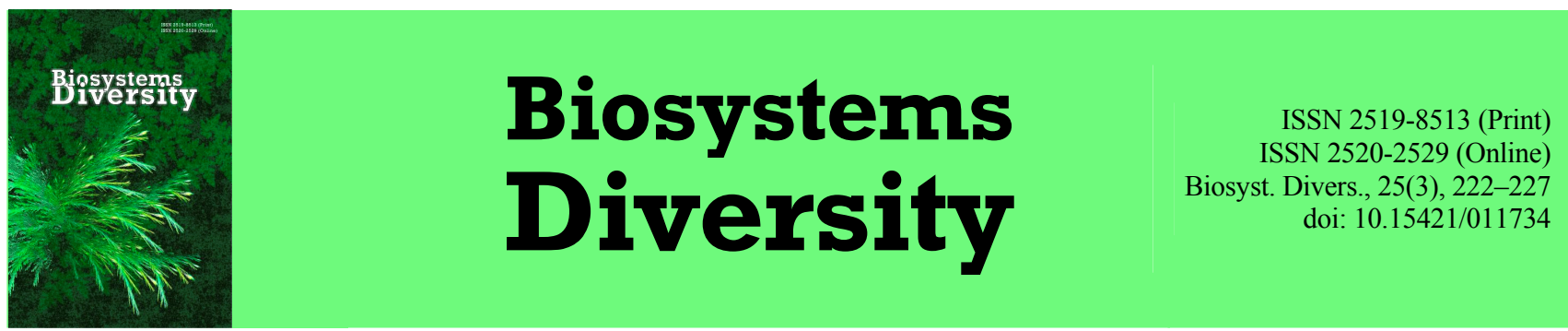

\title{
Anthropogenic transformation of the flora of urbanoecosystems of the Northern Pryazov territories
}

\author{
S. Y. Maltseva, Y. I. Maltsev, A. M. Solonenko, O. G. Bren \\ Bogdan Khmelnitskiy Melitopol State Pedagogical University, Melitopol, Ukraine
}

Article info

Received 17.07.2017

Received in revised form 12.08.2017

Accepted 14.08.2017

Bogdan Khmelnitskiy Melitopol State Pedagogical University, Getmanska Str., 20,

Melitopol, 72312, Ukraine.

Tel.:+38-097-526-26-09.

E-mail:svetadm32@gmail.com

\begin{abstract}
Maltseva, S. Y., Maltsev, Y. I., Solonenko, A. M., \& Bren, O. G. (2017). Anthropogenic transformation of the flora of urbanoecosystems of the Northern Pryazov territories. Biosystems Diversity, 25(3), 222-227. doi:10.15421/011734
\end{abstract}

\begin{abstract}
The paper provides a thorough analysis of the current situation about biodiversity of model city in the Nothern Pryazov territories - Henichesk (Kherson region). The urban flora species composition of this city is represented at first time. There are 507 species, which belongs to two divisions, 61 families and 233 genera. Urban flora was analyzed in systematical, biomorphological and environmental aspects. The species richness of families of the studied urban flora is characterized by a predominance of families which include 1-2 species. The most part of urban flora species are herbaceous plants $-80.1 \%$ (406 species), including herbaceous monocarpics -236 species and herbaceous policarpics 170. It was found that terophytes have prevalence $-36.1 \%$ by the types of biological species in the urban flora of Henichesk, the second place takes hemicryptophytes $-31.9 \%$. Other biological types are represented in a small quantity $-32 \%$. An important characteristic of flora is species distribution for the main types of vegetation (rythmologic groups). The dominated status in the researched urban flora set the summer green plants -430 species $(84.8 \%)$. Analyzing the position of the aerial shoot for the leaves position we have differed rosette, semirosette and rosetteless plants. Species with rosetteless shoot are dominating. Rhizomeless species in the flora of Henichesk are dominating (51.1\%) and species with caudex (23.6\%), indicating the dominance of xerophytic habitats and increased soil density in cities. The largest environmental group is a group of moderate moisture, which consists of 349 species $(68.8 \%$ of the total species number). There is predominance of heliophilous and shade-tolerant species, and mezotrophs. Adventive component of Henichesk flora has 217 species (159 genera and 52 families). The most part among them kenophytes, xenophytes, epecophytes. It was found that Henichesk have specific urban flora that combines elements of natural flora and typical urban components.
\end{abstract}

Keywords: urban flora; Nothern Pryazov territories; biodiversity; adventive fraction

\section{Introduction}

The researches of vascular plant flora of the Northern Pryazov territories received much attention by scientists and mainly concerns natural ecosystems (Dudina and Sheliag-Sosonko, 1995; Kolomiychuk, 2012). The consequence of increasing urbanization in modern world is in the field of knowledge of various sciences. The most important aspect of this problem is to monitor the biodiversity of urban areas as the main condition of sustainable development (Bezushko et al., 2009; Shekhovtseva and Mal'tseva, 2015).

There not so much researches about urban flora of the Northern Pryazov'ye. Urban flora of Henichesk (one of the Northern Pryazov'ye cities with an interesting history of economic development) has a particular interest. Modern flora of vascular and nonvascular plants in this region develops in the conditions of active commercial activity (Burda, 1997; Sudnik-Wójcikowska and Moysiyenko, 2008, 2011; Scherbina et al., 2014; Derevyanska and Glukhov, 2016; Maltsev et al., 2017). Anthropogenic transformation leads to changes in vegetation, natural plant communities transform into floral synanthropic (Burda, 1991; Sal'nikov and Pilipenko, 2005; Kuhn and Klotz, 2006; Muratet et al., 2007; Knapp et al., 2010; Fagot et al., 2011; Williams et al., 2015). As a result, there are changes of qualitative and quantitative character in native and adventive fractions in flora. For example, the last one is enriched by the new naturalization of extraneous and some cultivated species (Sukopp, 2002; Celesti-Grapow et al., 2006; Protopopova et al., 2006; La Sorte et al., 2007; Loeb, 2012; Gunnarsson et al., 2017). In this regard, the importance of identifying the new adventive species and their further monitoring in this area increases (Nazarov et al., 2001; Protopopova et al., 2006; Trentanovi et al., 2013; Protopopova and Shevera, 2014; Ćwikliński, 2017). Recently flora replenished by non-aboriginal plants through their conscious (cultivation) and spontaneous (with seeds of other plants, by vehicles, etc.) migration (Pyšek, 1993, 1998; Kowarik, 1994; Jenkins and Parker, 2000; Ricotta et al., 2009; Lososova et al., 2011; 2012).

\section{Materials and methods}

Material for this study was collected in the original fieldwork and represented in herbarium during the spring and autumn period in 2013-2015. In addition, the available fragmentary literature data are included (Dudina and Sheliag-Sosonko, 1995; Burda, 1997; Kolomiychuk, 2012; Shumilova and Fedoronchuk, 2013; Protopopova and Shevera, 2014; Maltseva and Solonenko, 2015; Maltseva, 2015, 2016; Derevyanska and Glukhov, 2016; Maltseva and Maltsev, 2017) and herbarium data obtained from Bogdan Khmelnitskiy Melitopol State Pedagogical University (MELIT). The names of species are represented by "Vascular plants of Ukraine. A nomenclatural checklist" (Mosyakin and Fedoronchuk, 1999). Analysis of species diversity of flora was made by the conventional morphological, ecological and geographic methods and with a method of comparative floristic. To analyze the biomorphological structure of urban flora of Henichesk we have chosen biomorphological features that are practically independent from the influence of environmental factors (Raunkiaer, 1936; Didukh, 2004; Ricotta et al., 2009). Analyzing the adventive fraction, the independent 
attributes were used: the time and method of migration, the degree of naturalization (the level of adaptation to new geographical conditions) (Schroeder, 1969; Sudnik-Wójcikowska, 1988; Ricotta et al., 2010).

\section{Results}

Henichesk ( $\left.46^{\circ} 10^{\prime} \mathrm{N}, 34^{\circ} 47^{\prime} \mathrm{E}\right)$ - is a central city of Henichesk district, Kherson region in the southern part of Ukraine. The first mention of Henichesk belongs to 1784, when a small settlement Ust-Azov appeared on the banks of the Azov Sea and Sivash (laterHenichesk) (Maltseva, 2015). The city area is $60383 \mathrm{~km}^{2}$, population - 21,633.

The species composition of urban flora of Henichesk includes 507 species of trees, shrubs and herbaceous plants that belong to 233 genera and 61 families (Table 1). Basis of flora consists of angiosperms $-98.4 \%$ of total species quantity. Class Liliopsida is represented by $12.4 \%$ of total families' quantity, $19.3 \%$ - genera and $13.6 \%$ - species, Magnoliosida - 80.3\%, 78.6\%, and $84.8 \%$ respectively.

Table 1

Quantitative composition of flora by department and class

\begin{tabular}{lrrrrrr}
\hline \multirow{2}{*}{ Phyla and classes } & \multicolumn{2}{c}{$\begin{array}{c}\text { Quantity } \\
\text { of species }\end{array}$} & \multicolumn{2}{c}{$\begin{array}{c}\text { Quantity } \\
\text { of genera }\end{array}$} & \multicolumn{2}{c}{$\begin{array}{c}\text { Quantity } \\
\text { of families }\end{array}$} \\
\cline { 2 - 7 } & abs. & \multicolumn{1}{c}{$\%$} & abs. & \multicolumn{1}{c}{$\%$} & abs. & $\%$ \\
\hline Pinophyta & 8 & 1.6 & 5 & 2.1 & 2 & 3.3 \\
Magnoliophyta & 499 & 98.4 & 228 & 97.9 & 59 & 96.7 \\
$\quad$ Magnoliopsida & 430 & 84.8 & 183 & 78.6 & 49 & 80.3 \\
Liliopsida & 69 & 13.6 & 45 & 19.3 & 10 & 16.4 \\
$\quad$ Total & 507 & 100.0 & 233 & 100.0 & 61 & 100.0 \\
\hline
\end{tabular}

The predominance of angiosperms in the flora, and among them the species of the dicotyledon class as a whole, is because they are more resistant to the stress factors that exist in the urban environment (Burda, 1991; Kuhn and Klotz, 2006; Knapp et al., 2010; Lososova et al., 2012; Dobbs et al., 2017).

The leading families in the studied urban flora are Asteraceae (66 species, $13 \%$ ), Poaceae $(50 ; 9.8 \%)$, Brassicaceae (44; 8.6\%), Rosaceae $(28 ; 5.5 \%)$, Fabaceae $(25 ; 4.9 \%)$, Boraginaceae $(22 ; 4.3 \%)$, Caryophyllaceae (22; 4.3\%), Lamiaceae (13; $2.5 \%)$, Scrophulariaceae and Apiaceae (11 each of them; $2.1 \%$ ) (Table 2). In the flora of Henichesk, two first places belong to the families Asteraceae, Poaceae, which is typical for holarctic floras in general and for many regions and cities (Malyshev, 1972; Pyšek, 1993; Luck and Smallbone, 2011; Maltseva and Solonenko, 2015). Ten leading families consist of $57.1 \%$ of specific and $56.0 \%$ of generic diversity of flora.

Table 2

Family spectrum of the flora of Henichesk

\begin{tabular}{lccc}
\hline \multirow{2}{*}{ Family } & \multicolumn{2}{c}{ Species quantity } & \multirow{2}{*}{ Rank } \\
\cline { 2 - 3 } & abs. & $\%$ & \\
\hline Asteraceae & 66 & 13.0 & 1 \\
Poaceae & 50 & 9.8 & 2 \\
Brassicaceae & 44 & 8.6 & 3 \\
Rosaceae & 28 & 5.5 & 4 \\
Fabaceae & 25 & 4.9 & 5 \\
Boraginaceae & 22 & 4.3 & $6-7$ \\
Caryophyllaceae & 22 & 4.3 & $6-7$ \\
Lamiaceae & 13 & 2.5 & 8 \\
Scrophulariaceae & 11 & 2.1 & $9-10$ \\
Salicaceae & 11 & 2.1 & $9-10$ \\
\multicolumn{1}{c}{ Total } & 292 & 57.1 & - \\
\hline
\end{tabular}

Quite high status has family Brassicaceae and it is typical for Mediterranean and Iranian-Turanian areas, and typical for the urban environment среды (Malyshev, 1972; Burda, 1991, 1997; Protopopova and Shevera, 2014; Maltseva and Solonenko, 2015). It is connected with the synanthropization of the flora, as well as with the biological characteristics of the species of this family (greater seed productivity). In the Mediterranean flora, this family takes from the 5th to 7 th rank, and in Boreal from the 5th to 6th. In the natural flora of Northern Pryazov'ye and in the coastal zone of the Azov Sea this family takes 8 th and 4th ranks respectively in the spectrum of leading families. In a city where occurs xerophytization of growth conditions, the role of xerophytic families Rosaceae (4th rank) and Fabaceae (5th rank) increases, they easily find free ecological niches for themselves, competing with native species. The increase in the role of the Rosaceae family is also associated with the peculiarities of plant introduction in the city and its environs because the greatest number of introducents belongs to this family.

Ten leading families of local component flora of Henichesk comprise together 105 species $(58.5 \%$ of the native species of urban flora). There are 85 genera concentrated in the top ten families (55.4\% of all the native component families). Small number of species represents most of the native faction families in the urban flora: each of the nine families includes only two species $(16.3 \%$ of the local component families in urban flora). Each of 22 families includes only one specie (40.2\%), for example, Euphorbiaceae, Aceraceae, Paeoniaceae, Typhaceae.

The species richness of families of the studied urban flora is characterized by presence of large number of families, which include 1-2 species (amounting to 32 families or 52.4\% of total urban flora families).

The most number of representatives was noticed for genera Euphorbia (eight species, 1.6\% of the total number of species), Chenopodium (7 species; 1.3\%), Artemisia (6 species, 1.1\%), Atriplex (5 species, 1.0\%). Twelve leading genera include $11.2 \%$ of total species number. The generic spectrum of the urban flora is closely resembles to the spectrum of the natural steppe flora of the Northern Azov Sea (Kolomiychuk, 2012).

The most part of urban flora species are herbaceous plants $80.1 \%$ (406 species), including herbaceous monocarpics - 236 species and herbaceous policarpics - 170 (Table 3). The percentage of trees and shrubs do not exceed $18.1 \%$ ( 92 species). The percentage of woody plants in total does not exceed $18.1 \%$ (92 species). It is worth noting that some species, under certain conditions, can change the life form (tree or shrub), for example, Elaeagnus angustifolia L., E. argentea Pursh, Sorbus aucuparia L., Cerasus mahaleb (L.) Mill. (Maltseva, 2016). The shrubs are used in city gardening as hedges, in the group plantings, as well as along roadways (Maltseva, 2016).

Table 3

Biomorphological spectrum of the Henichesk flora

\begin{tabular}{lrc}
\hline \multicolumn{1}{c}{ Living form } & \multicolumn{2}{c}{ Species quantity } \\
\cline { 2 - 3 } & abs. & $\%$ \\
\hline Trees & 44 & 8.7 \\
Shrubs & 33 & 6.5 \\
Low shrub & 3 & 0.6 \\
Tree or shrub & 10 & 1.9 \\
Ligneous & 2 & 0.4 \\
\multicolumn{1}{c}{ Total } & 92 & 18.1 \\
\hline Semi-shrub & 7 & 1.4 \\
Low semi-shrub & 2 & 0.4 \\
\multicolumn{1}{c}{ Total } & 9 & 1.8 \\
\hline Herbal monocarpics & 236 & 46.6 \\
Herbal polycarpics & 170 & 33.5 \\
\multicolumn{1}{c}{ Total } & 406 & 80.1 \\
\hline \multicolumn{1}{c}{ Altogether } & 507 & 100.0 \\
\hline
\end{tabular}

Participation of bushes and semi-bushes does not exceed $2 \%$. It shows that studied flora have a plain landscape features. According to other researchers of urban flora (Sal'nikov and Pilipenk, 2005; Knapp et al., 2010; Rysiak and Czarnecka, 2017) bushes and semibushes are among the least stable groups against the effects of urbanization. Predominance of monocarpics is caused by the invasion of adventive plants - there are 179 species of adventive monocarpics (54.7\% of the total) in the studied urban flora. There are 146 annual plant species (44.6\%). Many annuals are cultivars - Anethum graveolens L., Antirrhinum majus L., Calendula officinalis L., Cosmos bipinnatus Cav., Petunia atkinsiana (Sweet) D. Don ex Loudon. Another part of annuals - ruderal species which have become a common plants and firmly hold its position in the ecotopes because of the high 
seed productivity and prolonged area capturing (Aegilops cylindrica Host, Ambrosia artemisiifolia L., Chenopodium polyspermum L., Setaria viridis (L.) P. Beauv., Urtica urens L.).

As a result of analysis of biological species types of urbanoflora of Henichesk it was found that that almost the same number have terophytes $36.1 \%$ (183 species) and hemicryptophytes - 31.9\% (162 species) (e. g., Lactuca serriola L., Geum urbanum L., Carduus acanthoides L., Chelidonium majus L., Chondrilla latifolia M. Bieb., Senecio jacobaea L., etc.) (Fig. 1). Significant part of terosphyt (Aegilops cylindrica, Alyssum desertorum (Stapf) Botsch., Artemisia annua L., Cardamine parviflora L., Digitaria sanguinalis (L.) Scop.) is a feature of xeric conditions of Ancient Mediterranean areas (Moysiyenko, 1999). Other biological types are represented in a small amount and their total percentage is $32 \%$.

The next position is occupied by the phanerophytes -82 species, $16.2 \%$. There is a significant number of wildered introducent species among the woody plants (for example Acer negundo L., Ailanthus altissima (Mill.) Swingle, Catalpa bignonioides Walter, Cerasus vulgaris Mill., Lonicera tatarica L., Prunus stepposa Kotov, Robinia viscosa Vent.).

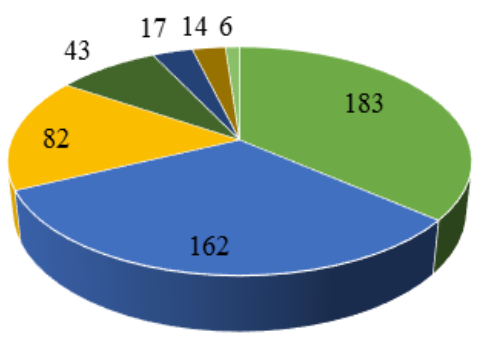

$$
\begin{array}{ll}
\text { " Terophytes } & \text { " Hemicryptophytes } \\
\text { " Phanerophytes } & \text { - Cryptophytes } \\
\text { - Terophytes and hemicryptophytes } & \text { " Hamephytes } \\
\text { " Geophytes } &
\end{array}
$$

Fig. 1. Spectrum of biological types of plants of the Henichesk flora (by K. Raunkier)

High terophytes diversity and reducing the role of hamephytes and cryptophytes - is a characteristic feature of the whole urban flora (Burda, 1991; Lososova et al., 2011). Increasing the part of terophytes in flora of urban areas indicates a weak level of plant community's formation. It caused by their high naturalization ability (by the intensive seed reproduction, the presence of open disturbed habitats suitable for their growth, weakening competition from perennials).

An important characteristic of flora is species distribution for the main types of vegetation (rythmologic groups) (Table 4). The dominated status in the researched urban flora set the summer green plants -430 species $(84.8 \%)$. Analyzing the position of the aerial stems for the leaves position, we have differed rosette, semirosette and rosetteless plants (Table 4). Species with rosetteless shoot are dominating -346 species $(68.2 \%)$; the second place takes semirosette plants -134 (26.4\%) in urban flora of Henichesk. Species with rosette shoots were not much characteristic for the investigated urban flora (5.4\% of total number of species). Rhizomeless species in the flora of Henichesk are dominating (51.1\%) and species with caudex (23.6\%), indicating the dominance of xerophytic habitats and increased soil density in cities. Such quite large percentage of rhizomeless type of structures is mainly represented mainly by annual herbaceous monocarpics. It can be explained by the complex edaphic nature of ecotope (high or low substrate density, chemical pollution and low soil aeration), formed in cities. Structure of underground shoots closely correlates with plant root types. Thus, there is a significant part of species with a taproot system $-349(68.9 \%)$ in the surveyed urban flora. This type of root system in all urban flora fractions was investigated.

To understand the specific features of the influence of the urban environment on the flora, it is necessary to establish the ecological groups

\begin{tabular}{|c|c|c|}
\hline \multirow{2}{*}{ Living form } & \multicolumn{2}{|c|}{ Species quantity } \\
\hline & abs. & $\%$ \\
\hline \multicolumn{3}{|c|}{ Main types of vegetation } \\
\hline Evergreen plants & 11 & 2.2 \\
\hline Winter green plants & 16 & 3.1 \\
\hline Summer green plants & 430 & 84.8 \\
\hline Summer-winter & 20 & 3.9 \\
\hline Ephemeral plants & 16 & 3.2 \\
\hline Ephemeroids & 14 & 2.8 \\
\hline \multicolumn{3}{|c|}{ Type of aerial stems } \\
\hline$\overline{\text { Rosette }}$ & 27 & 5.4 \\
\hline Semirosette & 134 & 26.4 \\
\hline Resetteless & 346 & 68.2 \\
\hline \multicolumn{3}{|c|}{ Type of underground stems } \\
\hline Rhizomeless & 259 & 51.1 \\
\hline Deep-rooting & 45 & 8.9 \\
\hline Shallow-rooting & 67 & 13.2 \\
\hline With caudex & 120 & 23.6 \\
\hline Caudex-shallow-rooting & 4 & 0.8 \\
\hline Alliaceous & 8 & 1.6 \\
\hline Tuber & 4 & 0.8 \\
\hline \multicolumn{3}{|c|}{ Root system type } \\
\hline Taproot & 349 & 68.9 \\
\hline Fibrous & 118 & 23.2 \\
\hline Taproot-fibrous & 39 & 7.7 \\
\hline Without roots or rhizomes & 1 & 0.2 \\
\hline Total & 507 & 100.0 \\
\hline
\end{tabular}
of plants it constitutes. We have conducted an ecological analysis of the urbanoflora of the Northern Pryazov territories based on three environmental factors: humidity, lighting and soil fertility (Fig. 2, 3, 4).

Table 4

The main types of vegetation (rythmologic groups)

of Henichesk urbanoflora

The largest environmental group is a group of moderate moisture, which consists of 349 species ( $68.8 \%$ of the total species number). The group includes xeromezophytes (197 species, 38.5\%) mezophytes $(139 ; 27.4 \%)$ and hygromezophytes $(13 ; 2.6 \%)$. Second place takes a group of drought-tolerant species, which includes xerophytes $(67 ; 13.2 \%)$ and mezoxerophytes $(77 ; 15.2 \%)$. There are 144 species (28.4\%) in this group. Such high rates of xerophytes are caused by the influence of anthropogenic pressure and confinement of the studied area to the Steppe zone of Ukraine.

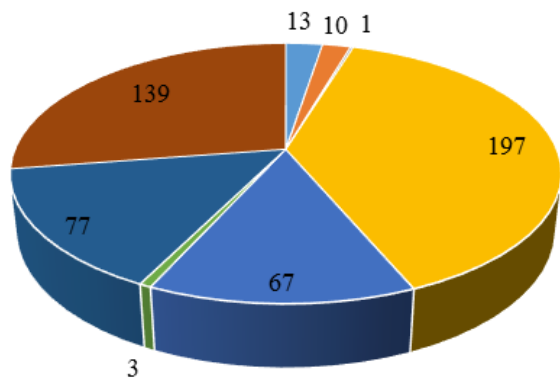

$$
\begin{aligned}
& \text { " Hygromezophytes " Hygrophytes " Hydrophytes } \\
& \text { "Xero-mezophytes - Xerophytes " Mezo-hygrophytes } \\
& \text { - Mezo-xerophytes - Mezophytes }
\end{aligned}
$$

Fig. 2. Distribution of flora species of Henichesk in relation to humidity

One of the most important environmental factors in the plants' life is light. There is predominance of heliophilous and shade-tolerant species $(73.0 \%$ of the urban flora species) that can be associated with the presence in a large number of well-lit areas. Shade-requiring and light-tolerant species mainly grow in less disturbed habitats (green areas, parks, gardens) $-27.0 \%$ of species.

Among the species of investigated urbanoflora, with respect to the fertility of the soil, prevail the plants that grow on soils with an average nutrient content-mezotrophs (41.2\% or 209 species) (Amaranthus retroflexus L., Narcissus poeticus L., Triticum aestivum L., Torilis arvensis (Huds.) Link, etc.). The prevalence of mesotrophs in 
the ecological spectrum is often noted by various authors in different regions of Ukraine, and in many fractions of the flora.

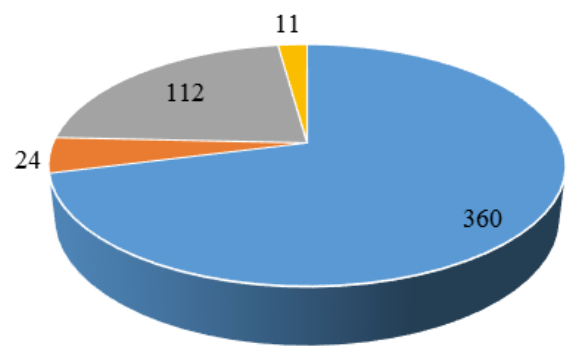

- Heliophytes " Heliosciophytes "Scioheliophytes "Sciophytes

Fig. 3. Distribution of flora species of Henichesk in relation to lighting conditions

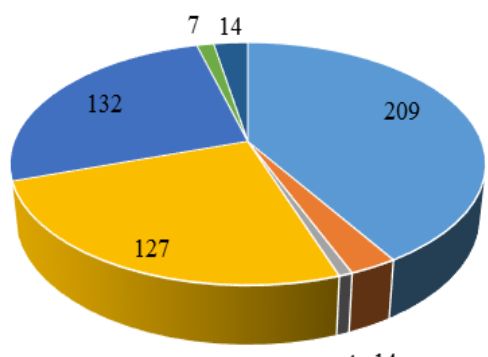

414

$\begin{array}{lll}\text { " Mezotrophs } & \text { " Oligotrophs } & \text { " Glycotrophs } \\ \text { " Eutrophs } & \text { - Semieutrophs } & \text { "Semioligotrophs } \\ \text { - Subglycotrophs } & & \end{array}$

Fig. 4. Distribution of flora species of the Henichesk in relation to the soil fertility factor

We consider the synanthropization as an increase in the share of synanthropic species in flora participation. To synanthropic plants we attribute anthropophytes in the composition of which we distinguish the adventitive and aboriginal parts (Table 5).

Table 5

Composition of anthropophytic element of the Henichesk flora

\begin{tabular}{lrr}
\hline \multirow{2}{*}{ Groups and subgroups } & \multicolumn{2}{c}{ Species quantity } \\
\cline { 2 - 3 } \multicolumn{1}{c}{ Anthropophytes } & abs. & $\%$ \\
\hline Apophytes & 366 & 72.2 \\
Advent & 155 & 30.6 \\
\hline \multicolumn{1}{c}{ Including the time of migration } & 211 & 41.6 \\
Archaeophytes & 80 & \\
Kenofits & 131 & 15.8 \\
\hline \multicolumn{1}{c}{ Including the way of migration } & & 25.8 \\
Xenophytes & 96 & \\
Ergasiofity & 87 & 18.9 \\
Acolyutophytes & 28 & 17.2 \\
\hline Including the degree of naturalization & & 5.5 \\
Epecophytes & 121 & \\
Agriophytes & 23 & 23.9 \\
Ergasiophytes & 51 & 4.5 \\
Ephemerophytes & 16 & 10.1 \\
\hline & 211 & 3.1 \\
\hline
\end{tabular}

Adventive component of Henichesk flora has 211 species (159 genera and 52 families). By the time of migration, kenophytes predominate - 131 species, which is typical for the flora of the Northern Azov Sea and the flora of Ukraine (Protopopova et al., 2006).

The most part among the adventitious species of the investigated urbanoflora are xenophytes (randomly introduced species that are spread because of anthropogenic transformation) $18.9 \%$, or 96 species, such as Anisantha tectorum (L.) Nevski, Cardaria draba (L.) Desv., Reseda lutea L., etc. Plants that become wild near the places of human cultivation - ergasiophytes - occupy the second place in the total number of species ( 87 species, or $17.2 \%$ ). The most common among them are Acer negundo, Amorpha fruticosa L., Calendula officinalis etc. The advent element of Henichesk has 28 species of acolyutophytes, or $5.5 \%$, this group is most interesting for establishing specific ways of invasion of adventitious plants. After all, they are brought in not too long ago, they grow locally near the place of their migration, and therefore it is possible to accurately determine the centers of invasion of these species.

Analysis of adventive species of Henichesk shows that the main ways of migration is a transport network, urban planting of greenery, adjacent agricultural landscapes. The dominance of the ancient mediterranean origin (Mediterranean, Mediterranean-Iran-Turanian and Iranian-Turanian) is noticed, constituting $56.6 \%$ of the total number of adventive species in the studied flora.

\section{Discussion}

A sufficient number of studies have been devoted to the investigation of anthropogenic changes of the vegetation cover (Pyšek, 1998; Lososova et al., 2011). Also intensively studying the change of systematic diversity in urbanization (Sudnik-Wójcikowska, 1988; Burda, 1991). The urban environment is a new transformed natural environment, which is characterized by a number of characteristics that determine this habitat for plants (Dobbs et al., 2017, Gunnarsson et al., 2017). An adequate amount of work has been devoted to the anthropogenic changes in the vegetation cover (Pyšek, 1998; Lososova et al., 2011). Including intensively studying the change in systematic diversity in urbanization (Sudnik-Wójcikowska, 1988; Burda, 1991). The urban environment is a new transformed natural environment, which is characterized by a number of environmental characteristics that determine the habitat conditions for plants (Dobbs et al., 2017; Gunnarsson et al., 2017).

Analyzing the systematic structure of model city Henichesk (Northern Pryazov territories), it was noted that the basis of flora constitute Magnoliophyta, representatives of Magnoliopsida are dominating among them. A significant decrease of monocots is specific for urban floras (Sudnik-Wójcikowska, 1988; Burda, 1991; Celesti-Grapow et al., 2006; Knapp et al., 2010). Our results are consistent with the data (Luck and Smallbone, 2011; Trentanovi et al., 2013) that the higher spore-bearing plants do not tolerate even a slight degree of anthropogenic influence and the lack of these plant groups is specific for the studied urban flora. Range of leading families of Henichesk flora is consistent with the spectrum of the majority of European urban floras (Kowarik, 1994; Lososova et al., 2011; Knapp et al., 2017), but with a few permutations. Therefore, the leading position of Asteraceae and Poaceae is specific for the spectrum of Holarctic flora and regional natural flora (Malyshev, 1972; Kolomiychuk, 2012). Nevertheless, the increase in rank of synanthropic thermophilic families Brassicaceae, Rosaceae, Fabaceae, Boraginaceae reflects the extreme conditions of the urban environment. Thus, the flora of Henichesk as a model city of the Northern Pryazov territories, undergoing a significant transformation, retains its zonal features in a systematic structure. Urbanoflora become more appropriate to more southerly and developing flora of extreme conditions by the presence of adventive fraction. This fact is consistent with other studies (Jenkins and Parker, 2000; Bezushko et al., 2009; Lososova et al., 2012).

Our results differ from the studies of regional natural flora and in the urban floras of the temperate zone (Burda, 1991, 1997; SudnikWójcikowska and Moysiyenko, 2011; Kolomiychuk, 2012; Rysiak and Czarnecka, 2017). There is a prevalence of herbaceous monocarpic plants in Henichesk, whereas the prevalence of herbaceous polycarpic plants is specific for the above-mentioned flora. Increase of the herbaceous monocarpic proportion, especially annuals, in the flora of the studied city is due to the adventitious species and tells about the acquisition of specific features, because of anthropogenic transformation. Strengthening position of young herbaceous plants expresses instability and vulnerability of urban flora according to Burda (1991), which conducted the study of the southeast of Ukraine. 
The flora of Henichesk recorded a prevailing of terophytes (Fig. 1). According to Knapp et al. (2010), they are more widely represented in highly urbanized floras. According to Sudnik-Wójcikowska (1988), in Central Europe a high percentage of terophytes indicates a high anthropogenic effect, which is quite high in Henichesk (a resort city that has a developed network of roads, railways and sea routes). A decrease in the contribution of cryptophytes along the gradient of recreational transformation was also established (Williams et al., 2005). However, it should also be noted the increase of the phanerophytes' role (trees and shrubs) in the flora of Henichesk, due to the wildness of the introducers (Muratet et al., 2007). The data obtained are consistent with the most part of the city flora researchers (Kowarik, 1994; Pyšek, 1998, Kuhn and Klotz, 2006, Aronson et al., 2007; Ricotta et al., 2010; Maltseva and Solonenko, 2015) and anthropogenically disturbed floras (Bezushko et al., 2009).

Wittig and Becker (2010) showed in their studies that cities represent a special habitat complex where prevailing only certain plant species. The main adaptions for living in the city conditions are: the high lighting level, specific temperature (higher than in the vicinity of city), absence of confinement to wet soils, indifference to the reaction of the soil (or preferring $\mathrm{pH}$ not less than 6 , with some exceptions), adaption to eutrophication. As for the plant species noted in Henichesk, all these statements are confirmed (Table 4, Fig. 2, 3, 4).

The main trends in the anthropogenic transformation of flora are the impoverishment of the local flora and the emergence of adventitious plant species, accidentally introduced because of human economic activity and because of the introduced species wildering (Schroeder, 1969; Burda, 1991; Ricotta et al., 2009). Species of native flora have a variety of ecological amplitude ranges, show different ability to adapt to urban conditions life and it reflects in their activity (Sudnik-Wójcikowska, 1988). Williams et al. (2010, 2015) suggests a focusing on measuring of the specific response of morphological and functional plant's features under the stress conditions that accompany urbanization. Data processing, analysis of these results will facilitate a meta-analysis and will allow the comparison of the generalized results. In this case, the study of simple data types in many cities (for example, lists of urban flora) will continue to be useful, but targeted studies and experimental measurement of the relevant features are necessary to confirm the cause-effect processes that structure urban floras. It is revealed that today low-active stenotope species associated with a narrow range of ecological conditions become more rare in the cities, as well as ordinary steppe, littoral species become rare too (Gungor et al., 2008). During our research of the urban flora of Henichesk, it was not possible to note the a lot of rare and protected species that were included to the Abstract of the Pryazov region flora (Kolomiychuk, 2012). Conversely, many steppe species are widely distributed. A group of local apophyte species, which migrate to the synanthropic sites has been identified. This group of plants makes up to $30.6 \%$ of the total number of species in urbanoflora of Henichesk and it brings the data closer to the results of other researchers (Kuhn and Klotz, 2006).

The other side of anthropogenic transformation is the emergence of adventive species. The increase of number and diversity of anthropogenic disturbed natural ecotopes and the emergence of new niches promotes the introduction of alien species into synanthropic and disturbed natural sites (Kowarik, 1994; Protopopova and Shevera, 2014). It was shown by studies that adventive plants quickly become dominant species that contribute not only the disturbance of the structure of vegetation cover but also to the biodiversity reduction in general (Schroeder, 1969, Pyšek, 1993; Kowarik, 2008; Grapow et al., 2006; Ricotta, 2010). Analysis of the adventive species of Henichesk showed that the main ways of their entry are the road transport network, urban landscaping, and adjoining agricultural landscapes. Transport and trade activities increase the possibility of new species immigration according to the researches (Fagot et al., 2011; Sukopp, 2002).

Accidentally introduced plants are prevailing by way of migration. This fact indicates the intensity of flora formation processes and their non-directional character. Similar processes are typical for other cities (Celesti-Grapow et al., 2006; Ricotta et al., 2010; Lososova et al., 2011). Prevalence of the representatives with ancient Mediterranean origin among the adventive plant species confirms the influence of urbanization on the flora aridization process (Burda, 1991; Pyšek, 1998; Loeb, 2012). There is a prevalence of naturalized species (epecophytes) in the adventive component of the flora of Henichesk. These species are fixed in the flora and spreading over the disturbed habitats. Today in Ukraine, we can notice facilitation of naturalization for some ergasophyte species and the growth suppression of some local flora species. These processes are caused by climatic changes, amplification of the mesophytic conditions of ecotopes in the Steppe zone. (Protopopova and Shevera, 2014).

\section{Conclusions}

Systematic, ecological, biological structures of urban flora of Henichesk were analyzed. It was established that species composition of urban flora of this city consists of 507 species that belong to two divisions, 61 families and 233 genera. Zonal features of urban flora of Henichesk were found because of systematic structure studies. Such features are expressed in the composition range of leading families and genera, major proportions and ratios.

The analysis of species distribution in the groups of biomorphological spectrum showed that flora of the city should be assessed as "terophytic-hemicryptophytic". Leading position of terophytes is explained by the strong transformation of vegetation in urban area. Thus, the morphological characteristics of urban flora of Henichesk are specific because the plant species should adapt to the urban environment where the limiting factor is soil compaction, transport zones factors, entire buildings conditions. The environmental structure of flora reflects the species proportion in the groups to the influence of abiotic factors dependence. The main routes of adventive species migration are transport network, urban planting of greenery, adjacent agricultural landscapes.

\section{References}

Aronson, M. F. J., Handel, S. N., \& Clemants, S. E. (2007). Fruit type, life form and origin determine the success of woody plant invaders in an urban landscape. Biological Invasions, 9(4), 465-475.

Bezushko, L. G., Mosyakin, S. L., \& Bezushko, A. G. (2009). Flora and vegetation of the Ovruch ridge (Northern Ukraine) in the early middle ages according to palynological evidence. Quaternary International, 203(1-2), $120-128$.

Burda, R. I. (1991). Antropogennaja transformacija flory [Anthropogenic transformation of the flora]. Naukova Dumka, Kyiv (in Russian).

Burda, R. I. (1997). Anotovanyj spysok flory promyslovyh mist na Pivdennomu Shodi Ukrai'ny [Annotated list of flora industrial cities in Southeast Ukraine]. BV, Donets'k (in Ukrainian).

Celesti-Grapow, L., Pysek, P., Jarosik, V., \& Blasi, C. (2006). Determinants of native and alien species richness in the urban flora of Rome. Diversity and Distribution, 12(5), 490-501.

Ćwikliński, E. (2017). Flora synatropijna Szczecina [The synanthropic flora of Szczecin]. Monographiae Botanicae, 33, 1-103 (in Polish).

Derevyanska, G. G., \& Glukhov, O. Z. (2016). Geografichna struktura urbanoflor stepovoji zony Ukrajiny [Geographical structure of the urban floras of steppe zone of Ukraine]. Biological Bulletin of Bogdan Chmelnitskiy Melitopol State Pedagogical University, 6(2), 239-245 (in Ukrainian).

Deutschewitz, K., Lausch, A., Kuhn, I., \& Klotz, S. (2003). Native and alien plant species richness in relation to spatial heterogeneity on a regional scale in Germany. Global Ecology and Biogeography, 12(4), 299-311.

Didukh, Y. P. (2004). Ekoflora Ukrajiny [Ekoflora of Ukraine], Fitosotsiotsentr, Kyiv (in Ukrainian).

Dobbs, C., Nitschke, C., \& Kendal, D. (2017). Assessing the drivers shaping global patterns of urban vegetation landscape structure. Science of the Total Environment, 592, 171-177.

Dudina, D. V., \& Sheliag-Sosonko, Y. R. (1995). Rastitel'nost' i ohrana Stepanovskoj kosy (Zaporozhskaja oblast') [Vegetation and protection of Stepanivska Spit (Zaporozhzhye region)]. Ukrainian Botanical Journal, 52(3), 409-414 (in Russian).

Fagot, M., Cauwer, B., Beeldens, A., Boonen, E., Bulcke, R., \& Reheul, D. (2011). Weed flora in paved areas in relation to environment, pavement characteristics and weed control. Weed Research, 51(6), 650-660. 
Gungor, B., Makineci, E., \& Murat, D. (2008). Revegetated herbaceous plant species on a compacted skid road. Journal of Terramechanics, 45(1-2), 45-49.

Gunnarsson, B., Knez, I., Hedblom, M., \& Ode Sang, A. (2017). Effects of biodiversity and environment-related attitude on perception of urban green space. Urban Ecosystem, 20(1), 37-49.

Hüse, B., Szabó, S., Deák, B., \& Tóthmérész, B. (2016). Mapping an ecological network of green habitat patchesand their role in maintaining urban biodiversity in and around Debrecen city (Eastern Hungary). Land Use Policy, 57, 574-581.

Jenkins, M., \& Parker, G. (2000). The response of herbaceous-layer vegetation to anthropogenic disturbance in intermittent stream bottomland forests of southern Indiana, USA. Plant Ecology, 151(2), 223-237.

Knapp, S., Küuhn, I., Stolle, J., \& Klotz, S. (2010). Changes in the functional composition of a Central European urban flora over three centuries. Perspectives in Plant Ecology, Evolution and Systematics, 12, 235-244.

Kolomiychuk, V. P. (2012). Konspekt flory sosudistyh rastenij beregovoj zony Azovskogo morja [Synopsis of the flora of vascular plants of coastal zone of the Sea of Azov]. Alterpres, Kyiv (in Russian).

Kowarik, I. (1994). Approaches to urban flora and vegetation in Central Europe. Giornale Botanico Italiano, 128(1), 201

Kuhn, I., \& Klotz, S. (2006). Urbanization and homogenization - comparing the floras of urban and rural areas in Germany. Biological Conservation, 127, 292-300

La Sorte, F. A., McKinney, M. L., \& Pyšek, P. (2007). Compositional similarity among urban floras within and across continents: biogeographical consequences of human-mediated biotic interchange. Global Change Biology, 13, 913-921.

Loeb, R. E. (2012). Arboricultural introductions and long-term changes for invasive woody plants in remnant urban forests. Forests, 3, 745-763.

Lososova, Z., Chytrý, M., Tichý, L., Danihelka, J., Fajmon, K., Hájek, O., Kintrova, K., Kuhn, I., Laniková, D., Otýpkova, Z., \& Řehořek, V. (2011). Native and alien floras in urban habitats: a comparison across 32 cities of central Europe. Global Ecology and Biogeography, 21, 545-555.

Lososova, Z., Chytrý, M., Tichý, L., Danihelka, J., Fajmon, K., Hájek, O., Kintrova, K., Laniková, D., Otýpkova, Z., \& Řehořek, V. (2012). Biotic homogenization of Central European urban floras depends on residence time of alien species and habitat types. Biological Conservation, 145, 179-184.

Luck, G. W., \& Smallbone, L. T. (2011). The impact of urbanization on taxonomic and functional similarity among bird communities. Journal of Biogeography, 38, 894-906.

Maltsev, Y. I., Pakhomov, A. Y., \& Maltseva, I. A. (2017). Specific features of algal communities in forest litter of forest biogeocenoses of the Steppe zone. Contemporary Problems of Ecology, 10(1), 71-76

Maltseva, S. Y. (2015). Ohranjaemye i redkie vidy v urbanoflore Genicheska [Rare and protected species in urban flora of Genichesk]. Biological Bulletin of Bogdan Chmelnitskiy Melitopol State Pedagogical University, 5(1), 105-114 (in Russian).

Maltseva, S. Y., \& Maltsev, Y. I. (2017). Novi znahidky u flori mist Pivnichnogo Pryazov'ja [New findings in urban flora of Northern Azov Sea region]. Ukrainian Journal of Ecology, 7(2), 55-58.

Maltseva, S. Y., \& Solonenko, A. N. (2015). Urbanoflora mista Prymors'k (Zaporiz'ka oblast', Ukrajina). [The urban flora of Primorsk (Zaporizhia region, Ukraine)]. Chernomorski Botanical Journal, 11(4), 433-437 (in Ukrainian)

Malyshev, L. I. (1972). Floristicheskie spektry Sovetskogo Sojuza. Istorija flory i rastitel'nosti Evrazii [Floristic spectra of the Soviet Union. History of flora and vegetation of Eurasia]. Nauka, Leningrad (in Russian).

Mosyakin, S. L., \& Fedoronchuk, M. M. (1999). Vascular plants of Ukraine. A nomenclatural checklist. M. G. Kholodny Institute Botany, Kyiv.

Muratet, A., Machon, N., Frédéric, J., Moret, J., \& Porcher, E. (2007). The role of urban structures in the distribution of wasteland flora in the greater Paris area, France. Ecosystems, 10(4), 661-671.
Nazarov, N., Cook, H. F., \& Woodgate, G. (2001). Environmental issues in the postcommunist Ukraine. Journal of Environmental Management, 63, 71-86.

Protopopova, V. V., \& Shevera, M. V. (2014). Ergasiophytes of the Ukrainian flora. Biodiversity Research and Conservation, 35(1), 31-46.

Protopopova, V. V., Shevera, M. V., \& Mosyakin, S. L. (2006). Deliberate and unintentional introduction of invasive weeds: A case study of the alien flora of Ukraine. Euphytica, 148, 17-33.

Pyšek, P. (1993). Factors affecting the diversity of flora and vegetation in central European settlements. Vegetatio, 106(1), 89-100.

Pyšek, P. (1998). Alien and native species in Central European urban floras: A quantitative comparison. Journal of Biogeography, 25(1), 155-163.

Raunkiaer, C. (1936) Life formas of plants and statistical plant geography, being the collected papers of Raunkiaer. Clarendon Press, Oxford.

Ricotta, C., Godefroid, S., \& Rocchini, D. (2010). Invasiveness of alien plants in Brussels is related to their phylogenetic similarity to native species. Diversity and Distributions, 16(4), 655-662.

Ricotta, C., La Sorte, F. A., McKinney, M. L., Pyšek, P., Klotz, S., Rapson, G. L., Celesti-Grapow, L., \& Thompson, K. (2009). Phytoecology of urban alien floras. Journal of Ecology, 97(6), 1243-1251.

Rysiak, A., \& Czarnecka, B. (2017). Richness of vascular flora in Lublin city, east Poland, under different urban pressure. Landscape and Ecological Engineering, 13(2), 213-228

Sal'nikov, A. L., \& Pilipenk, V. N. (2005). Anthropogenic transformation of flora in the city of Astrakhan and its environs over the past 100 years. Russian Journal of Ecology, 36(6), 383-390.

Scherbina, V. V., Maltseva, I. A., \& Solonenko, A. N. (2014). Peculiarities of postpyrogene development of algae in steppe biocenoses at Askania Nova Biospheric National Park. Contemporary Problems of Ecology, 7(2), 187-191.

Schroeder, F. G. (1969). Zur klassifizierung der anthropochoren [Classification of the anthropochoras]. Vegetatio Acta Geobotanica, 16(5-6), 225-238 (in German).

Shekhovtseva, O. G., \& Mal'tseva, I. A. (2015). Physical, chemical, and biological properties of soils in the city of Mariupol, Ukraine. Eurasian Soil Science, 48(12), 1393-1400.

Shumilova, A. V., \& Fedoronchuk, N. S. (2013). Gerbarij J. K. Bojko [Herbarium of J. K. Bojko]. Alterpress, Kyiv (in Russian).

Sudnik-Wójcikowska, B. (1988). Flora synanthropization and anthropopressure zones in a large urban agglomeration (exemplified by Warsaw). Flora, $180(3-4), 259-265$.

Sudnik-Wójcikowska, B., \& Moysiyenko, I. I. (2008). The floristic of microhabitats within kurgans in the desert stepp zone of southern Ukraine. Acta Societatis Botanicorum Polonie, 77(2), 139-147.

Sudnik-Wójcikowska, B., \& Moysiyenko, I. I. (2011). Anthropogenic elements of the Ukrainian landscape and the problem of local steppe restoration. Annales UMCS, Biologia, 66(1), 85-103.

Sukopp, H. (2002). On the early history of urban ecology in Europe. Urban Ecology, 79-97.

Trentanovi, G., Lippe, M., Sitzia, T., Ziechmann, U., Kowarik, I., \& Cierjacks, A. (2013). Biotic homogenization at the community scale: Disentangling the roles of urbanization and plant invasion. Diversity and Distributions, 19, 738-748.

Williams, N. S., Morgan, J. W., Mcdonnell, J. W., \& Mccarthy, M. A. (2005) Plant traits and local extinctions in natural grasslands along an urban rural gradient. Journal of Ecology, 93, 1203-1213.

Williams, N. S. G, Hahs, A. K., \& Vesk, P. A. (2015). Urbanisation, plant traits and the composition of urbanfloras. Perspectives in Plant Ecology, Evolution and Systematics, 17(1), 78-86.

Wittig, R., \& Becker, U. (2010). The spontaneous flora around street trees in cities - A striking example for the worldwide homogenization of the flora of urban habitats. Flora - Morphology, Distribution, Functional Ecology of Plants, 205(10), 704-709. 